\title{
Correction to: Pivotal qualities for effective university leadership on the basis of a modified Australian model: the application of FIMIX-PLS and IPMA in the Malaysian academic context
}

\section{Majid Ghasemy ${ }^{1}$. Sufean Bin Hussin ${ }^{1}$. Megat Ahmad Kamaluddin Bin Megat Daud ${ }^{1}$. Ahmad Zabidi Bin Abdul Razak ${ }^{1}$. Mohd Jamil Bin Maah ${ }^{2}$}

Published online: 27 November 2017

(c) Education Research Institute, Seoul National University, Seoul, Korea 2017

Correction to: Asia Pacific Educ. Rev.

https://doi.org/10.1007/s12564-017-9504-7

In Table 14 in the Appendix: the value $p^{2}$ under the Lowcurrent-tenure leaders model section is an erratum (spelling error) and should change to $f^{2}$.

The original article was corrected.

The online version of the original article can be found under https://doi.org/10.1007/s12564-017-9504-7.

Sufean Bin Hussin

drsufean@um.edu.my

Majid Ghasemy

majid_ghasemy@um.edu.my

Megat Ahmad Kamaluddin Bin Megat Daud

megat@um.edu.my

Ahmad Zabidi Bin Abdul Razak

zabidi@um.edu.my

Mohd Jamil Bin Maah

mjamil@um.edu.my

1 Department of Educational Management, Planning \& Policy, Faculty of Education, University of Malaya (UM), Kuala Lumpur, Malaysia

2 Department of Chemistry, Faculty of Science, University of Malaya (UM), Kuala Lumpur, Malaysia 